\title{
Enhanced Collaborative Teaching Method on the Performance of Students in Essay Writing Task
}

\author{
Timothy Kolade Akinwamide \\ Arts and Language Education Department, Ekiti State University, Ado Ekiti, Nigeria \\ Email: wamide.tk@gmail.com
}

\begin{abstract}
The art of Writing as a basic language skill in Language Education, is a generative skill that requires a lot of brainstorming in order for Second Language students to meet up with the acceptable communicative competence expected. Where and when individuals collaborate on a given work, the resultant effect is normally encouraging hence this research work examined the effects of collaborative teaching method on the writing task of students. The paperemployed the collaborative pedagogy on enhancing students' academic performance in essay writing at the Senior Secondary School level. The study adopted a quasi-experimental design approach. The sample consisted of 50 Senior Secondary School final year students. The data generated were subjected to statistical analysis and the results of the analysis showed that there was no significant difference between the pre-test scores of both the control and experimental group which established the homogenuityof both control and experimental groups before the application of treatment on the experimental group . There was no significant difference in the pre-test and post test scores of the students in control group. However the collaborative method which was the treatment had significant effect on students overall performance in essay writing. Therefore, it is recommended that English language teachers could employ this method for improved performance among students. Also, teachers should encourage teamwork among students for the exchange of novel ideas. To this effect, educational institutions could organise and train teachers on how to secure better performance through collaborative pedagogical inputs.
\end{abstract}

Keywords: Writing skill; Second Language; Collaborative pedagogy; Students Performance.

\section{Introduction}

Writing is a crucial language skill that enables people to express their feelings and thoughts. It is employed to clarify thought and ideas, to get convey information through prints and bytes. Banat (2007) points out that this skill is invaluable for helping students interact, communicate and understand issues of life. Akinwamide (2013) views writing as the ability to externalize previous internalised issues, through graphical presentation of thoughts, ideas, concepts and observing for the purpose of record and communication. The task of expressing oneself in the written form has been the aim of many teachers and students. However, with regards to learners of English as a Second Language Extraction (ESL), the teachers' effort to produce students who can demonstrate the skill of writing seems to be a herculean task. This is because writing skill is considered a complex cognitive skill since it requires the students to apply appropriate cognitive strategies, intellectual skills and appropriate motivations. For Faezah (2013), students face mental block and inability to connect grammar rules with sentence formation as well as the ineptness in using the rhetorical style of the target language. So, this problem makes it difficult for students of ESL to produce a piece of writing which is communicative, clear and concise. 
Writing is one of the four language skills that need to be mastered by language learners, thus concerted efforts have been exerted by researchers and educators to study the nature of the skill as well as the best methods that can be adopted to teach it effectively and productively. Akinwamide (2013) notes that writing as a skill demands students to plan and organize their imagination clearly and in sequential order to fulfil the essence of writing. In recent years, there has been a renewed interest in the writing process especially from a leaners' perspective. The ever declining written production performance by writers of different age levels in a variety of text type e.g. expository, argumentative or narrative texts should be a strong motivating factor in the development of new models about the writing process.

There are two earlier approaches that teachers have been adopting in teaching writing. The first approach is the product approach. The product approach focuses on the end result of the act of writing. It focuses on the different part of the text, words, sentences paragraph but there is not much focus on ideas and meaning. The role of the teacher is to examine the finished product focusing more on linguistic accuracy. Akinwamide (2003) states that the underlying principle of the product approach is that, if the teacher identifies a model, written by an accomplished and competent writer and this is given to student to read, the students then study the styles and the techniques of the expert writer and copy such perfect model, the students will become good writers. However, the written products were shown to be inadequate and were replaced by a new emphasis on the writing process and the writer's production context. Vanessa (2004) corroborates this view by stating that the product approaches does not allow students to write error laden texts, the focus is accuracy.

Another approach to writing is the process approach. The process approach focuses on how good writers actually write. Writers are seen as active thinkers who employ strategies to compose text. The strategies adopted are generating ideas, reviewing, evaluating, focusing, structuring and drafting. Writing is viewed both as a cognitive process and a socio-cultural activity. The cognitive model of writing is seen as a mental process involving decision making and problem solving. Hamer (2004) states that the skills in writing are not acquired but consciously learnt and transmitted. The students writing skills do not come naturally but are cultivated through much practice and conscious effort.

The paradigm shift from product approach to process approach has redefined and renegotiated the teacher's role. A teacher is no longer the authority figure in a writing class, but acts as a consultant and a facilitator in assisting the student to produce coherent, meaning and a creative piece of writing. The teachers' role has changed from an evaluator of the written product to a facilitator and co-participant in the process of writing. Khatijah (2004) affirms that the teacher is to provide a learning environment that will enable students to learn about writing, engage in writing and feel enthusiastic about writing.

Collaborative learning has become an essential concept in the field of education, also a well-known and widespread activity in English as Second Language (ESL) writing classes. The term collaborative learning as used in the study refers to student working together in small group on specific activities where everyone isrequired to participate actively. Under this situation the teacher stands as the facilitator, this method is learner-centered and activity based.

There are both theoretical and pedagogical base for the widespread use of methods and strategies in education. From theoretical point of view using collaborative interaction has become a topic of research in aspect of both education and social psychology, from a pedagogical perspective the use of peers and other groups is based on using the 
communicative approach to second language instruction that focuses on helping learners to function in the second language. Collaborative learning can also be viewed as small groups of learners working together as a team to solve problems, complete a task or accomplish a common goal. Graham (2005) states that collaborative learning differs from traditional learning because it provides structural opportunities for individuals who are given specific roles within their groups to work together to reach common goals. It is usually contrasted with traditional or competitive classroom environment, because when students learn individually, the performance does not necessarily affect one another either positively or negatively. Collaborative learning, on the other hand means putting them together first before operating individually for direct competition with oneanother knowing that the earlier team work will have effect on individual performances.

Collaborative learning in the context of collaborative writing means two or more people working together to produce and complete a text, through practicing stages and activities stages and activities such as collecting planning and organizing ideas, drafting, revising and editing. Akinwamide (2013) notes that these activities can be in three basic dimensions

i. $\quad$ Pre writing

ii. Composing and editing

iii. Final draft

Storch (2002) claims that collaborative learning in the form of collaborative writing in ESL classes might help students to act socially and cognitively and suggests that teachers should encourage learners to become involved in social activities that promote interaction and the construction of knowledge as well as create interpersonal and team skills. Even though collaborative learning is learner centred and teachers have a paramount role to play in structuring and planning the lessons.

Traditionally, classes always consist of good and weak students. The weak students sit in isolation as they gradually lose confidence in their ability to learn. Working in small groups, therefore is believed to help solve this problem as good members can complement each other strength and weaknesses. Students who do not like to speak in a large class are more comfortable in smaller groups.

In recent times, considerable number of researchers like Adekola (2014), Adeyemi (2008) Graham (2005) and Onabanjo (2000) have worked on the effectiveness of collaborative learning in different disciplines. All these point to the fact that collaborative learning could have positive effects higher achievement and more robust relationship among students.

\section{Second Language Learners' Writing Constraints}

Observation from previous research work and experience have revealed that second language students face a lot of problems in attempt to write in a foreign language. As a matter of fact, the language teachers in Nigeria are also Second Language Teachers who have their own limitations and hence neglect essay writing in classroom teaching because they find it difficult to teach it. It has been noted that students' inability to write a comprehensive acceptable essay may be as a result of the method of the teachers. Most teachers and educators are in dubious of the students' ability to acquire knowledge on their own. Most of the time students are left to wander about what and how to write. Akinwamide (2012) citing Oluwadiya (1992) notes that many teachers in Nigeria are not aware of the shift from the 
traditional writing approach while Vadivelloo and Vijayarajoo (2004) affirm that most educational practices are done with teacher-centred method which still remains a widely used instructional strategies to impact knowledge.

\subsection{Research Questions}

1. Will there be any difference between scores of students in the control and experimental groups at pretest?

2. What is the effect of treatment on the experimental group?

3. Will there be any difference between scores of the experimental and control groups at post test?

\subsection{Research Hypotheses}

In order to answer the questions raised on this study, the following null hypotheses were test at 0.05 level of significance.

1. There would be no significant difference between the pre-test scores of the students in the control and experimental groups

2. There would be no significant difference between the post test scores cores of the student in the control and experimental groups

3. There would be no significant difference between the pre-test and post-test scores of

2.3 Results the students in the experimental group

The data generated from the instrument were analysed using inferential statistics. Hypotheses $1-3$ were tested using t-test at 0.05 level of significance. The results are shown below:

Hypothesis 1: There is no significant difference between the pre-test scores of students in control and experimental groups

Table 1. t-test analysis of pre-test scores of students in control group and experimental group

\begin{tabular}{|c|c|c|c|c|c|c|}
\hline Variations & $\mathbf{N}$ & $\operatorname{Mean}(\bar{X})$ & SD & Df & t-cal & $\begin{array}{l}\text { t- } \\
\text { tab }\end{array}$ \\
\hline Control & $\begin{array}{l}2 \\
5\end{array}$ & 34.50 & 8.98 & \multirow{2}{*}{48} & \multirow{2}{*}{0.42} & \multirow{2}{*}{2.01} \\
\hline Experimental & $\begin{array}{l}2 \\
5\end{array}$ & 35.63 & 9.98 & & & \\
\hline
\end{tabular}

$\mathrm{P}<0.05$

Table 1 shows that the $t$-cal value of 0.42 is less than $t$-tab value of 2.01 at 0.05 level of significance, this implies that null hypothesis is not rejected. Hence, there is significant difference between the pre-test scores of students in control group and experimental group. Since there was no significant difference between the pre-test score of both groups, it shows that students in the two groups were homogeneous at the commencement of this study.

Hypothesis 2: There is no significant difference between the post-test scores of students in control group and experimental group

Table 2. t-test analysis of post-test scores of students in control and experimental groups

\begin{tabular}{|l|c|c|c|c|c|c|}
\hline Variations & N & Mean( $\bar{X}$ & SD & Df & t-cal & t-tab \\
\hline Control & 25 & 36.33 & 9.61 & \multirow{2}{*}{48} & \multirow{2}{*}{10.12} & \multirow{2}{*}{2.01} \\
\hline Experimental & 25 & 58.96 & 5.71 & & & \\
\hline
\end{tabular}

$* \mathrm{P}<0.05$ 
Table 2 shows that the $t$-cal value of 10.12 is greater than t-tab value of 2.01 at 0.05 level of significance; this implies that null hypothesis is rejected. Hence, there is significant difference between the post-test scores of students in control group and experimental group. The mean difference between experimental group and control group of 22.63 shows the effectiveness of experimental group over the control group.

Hypothesis 3: There is no significant difference between the pre-test scores and post-test scores of students in the experimental group.

Table 3. t-test analysis of pre-test and post-test scores of students in the experimental

\begin{tabular}{|l|c|c|c|c|c|c|}
\hline Variations & N & Mean( $\bar{X}$ & SD & Df & t-cal & t-tab \\
\cline { 1 - 4 } & & & & & & \\
\hline Pre-test & 25 & 35.63 & 9.98 & \multirow{2}{*}{48} & 10.15 & 2.01 \\
\hline Post-test & 25 & 58.96 & 5.71 & & \\
\hline
\end{tabular}

$* \mathrm{P}<0.05$

Table 3 shows that the $t$-cal value of 10.15 is greater than t-tab value of 2.01 at 0.05 level of significance, this implies that null hypothesis is rejected. Hence, there is significant difference between the pre-test scores and post-test scores of students in the experimental group.

\section{Discussion}

The findings of this study revealed that at take-off there was no significant difference between the pre-test scores of the students in the experimental and control group as evident in table one. This shows the homogeneity of the two groups. The two groups were tested based on the experience from the normal conventional class.

The effect of treatment on the experimental group showed a notable significant difference between the control and the experimental groups. In essence, enhanced collaborative learning in essay writing class produced significant positive learning outcome. Students performance showed a significant improvement in the post-test compared to the pretest. The enhancement of the students' writing performance can be attributed to collaborative learning method as this provides a platform for students to work with peers which could lead to a higher level thinking and understanding. Consequently the results of this study confirms the results of the study by Storch (2005) Kessel (2003)Ghorbani (2008) who all affirm that collaborative method improved students writing skills tremendously.

\section{Conclusion}

This study elucidates that collaborative learning enhances students writing performance. Before collaborative learning was incorporated in the lesson the students obtained low scores for the narrative essay. However, after the implementation of collaborative learning for four weeks the students scored significantly better in their essay writing.

\section{Recommendations}

English Language teachers could adopt this learning method for improved performances among students. Also teachers should encourage teamwork among students in order to work together productively. 
The curriculum planners and the school authorities should equally provide avenue for students in order to interact freely within each other.

Teachers training institutions should organise and train teachers on learner centred approach of teaching within the classroom setting.

Curriculum designers should incorporate collaborative learning activities in English class work and enough time should be given to the classroom practices to enable students function and participate well in any given task.

\section{References}

Adeloka, B.O. (2014) Collaborative Learning Method and its Effect on Student's Academic Achievement in reading comprehension. European Journal of Humanities and Social Sciences Vol. 32 No pp 1767-1775

Adeyemi B.A (2008) Effects of Collaborative Learning and Problem Solving Strategies on Junior Secondary School Student Achievement in Social Studies Electronic Journal of Research in Edu. Psychology Vol 6 (3) pp 691-708

Akinwamide, T.K (2003) The Effect of Guided and Free Exptression Methods on Students Performance in Essay Writing at the Senior Secondary School in Ekiti State, Nigeria. Unpublished M.ED Thesis Submit to the University of Ado- Ekiti, Ekiti State.

Akinwamide, T.K (2007) The Basics Approaches to the teaching of writing. In Oyinloye G O (ed) Language and Literature Teaching Methods. Matori Lagos, Biofial Publishers.

Akinwamide (2012) The influence of process Approach on English as Second Language Students' performance in essay writing. English Language Teaching Vol. 5. No 3

Akinwamide, T.K (2013) The Outcomes of Multiple - Draft Method on the Performance of Secondary School Students in Continuous Writing. Study in English Language Teaching Vol. No 1.

Banat S (2007) The effect of a program Based on developing EFL Writing Skills among Jordanian Secondary Stage Students. Unpublished Ph.D Thesis. Animan Arab University for graduate Studies. Aman Jordan.

Ghorbami, M. (2008) The Impact of Collocational Instruction on the Writing Skill of Iranian EFL Learners. A Case of Product and Process. Retrieved from http://www.amazon,com

Graham, D. (2005) Cooperative Learning Methods and Middle School Students Unpublished Ph.D .Thesis Capella University.

Kesseler, J.B (2003) A Survey of Faculty Experience using Cooperative Learning in Teacher Education. Unpublished Ph.D. Thesis Temple University.

Khatijah Johari (2004) Second Language writing: from knowledge to application. English Language Teaching, Transition in ELT: Challenges and prospects. Faculty of Education. University Kebangsaan Malaysia.

Onabanjo I.O (2000) Peer Tutoring, Parent Supporting Veness and Students' Locus of Control as Determinant of Learning Outcomes in Senior Secondary School Mathematics, Unpublished Ph.D Thesis, university of Ibadan.

Razavi, R. (2005) A Study of Impact Of Cooperative Learning on the Reading Performance of University ESP Students. Unpublished M.A Thesis Tabriz Islamic Azad University of Tabriz Branch.

Storch, N (2002) Patterns of Interactions in ESL Pair Work, Language Learning 52 Vol. 1 Pp $199-158$. 
Storch, N (2007) Investigating the Merits of Pair Work on a Text Editing Research II Vol. 2 Pp $143-159$.

Storch, N. (2005) Collaborative Writing: Product Process and Student reflections Journal of Second Language writing Vol 14 (3) pp 153- 173.

Vadivello, J \& Vijayarajoo, A. R (2004). Looking at some teaching strategies and skills found to be effective in today's classroom and how these can be made more effective.

Vanessa, S (2004) A Product and Process writing: A comparison. London British Council Educational Service. 